\title{
Malvinas-slope water intrusions on the northern Patagonia continental shelf
}

\author{
A. R. Piola ${ }^{1,2}$, N. Martínez Avellaneda ${ }^{3}$, R. A. Guerrero ${ }^{4}$, F. P. Jardón ${ }^{5}$, E. D. Palma ${ }^{6,7}$, and S. I. Romero ${ }^{1,2}$ \\ ${ }^{1}$ Departamento Oceanografía, Servicio de Hidrografía Naval, Buenos Aires, Argentina \\ ${ }^{2}$ Departamento de Ciencias de la Atmósfera y los Océanos, Facultad de Ciencias Exactas y Naturales, \\ Universidad de Buenos Aires, Argentina \\ ${ }^{3}$ Institut für Meereskunde, KlimaCampus, Universität Hamburg, Hamburg, Germany \\ ${ }^{4}$ Instituto Nacional de Investigación y Desarrollo Pesquero, Mar del Plata, Argentina \\ ${ }^{5}$ Laboratoire d'Océanographie et du Climat, Université de Paris VI, Paris, France \\ ${ }^{6}$ Departamento de Física, Universidad Nacional del Sur, Bahía Blanca, Argentina \\ ${ }^{7}$ Instituto Argentino de Oceanografía, CONICET, Bahía Blanca, Argentina
}

Received: 16 November 2009 - Published in Ocean Sci. Discuss.: 2 December 2009

Revised: 15 February 2010 - Accepted: 23 February 2010 - Published: 8 March 2010

\begin{abstract}
The Patagonia continental shelf located off southeastern South America is bounded offshore by the Malvinas Current, which extends northward from northern Drake Passage $\left(\sim 55^{\circ} \mathrm{S}\right)$ to nearly $38^{\circ} \mathrm{S}$. The transition between relatively warm-fresh shelf waters and Subantarctic Waters from the western boundary current is characterized by a thermohaline front extending nearly $2500 \mathrm{~km}$. We use satellite derived sea surface temperature, and chlorophyll- $a$ data combined with hydrographic and surface drifter data to document the intrusions of slope waters onto the continental shelf near $41^{\circ} \mathrm{S}$. These intrusions create vertically coherent localized negative temperature and positive salinity anomalies extending onshore about $150 \mathrm{~km}$ from the shelf break. The region is associated with a center of action of the first mode of nonseasonal sea surface temperature variability and also relatively high chlorophyll- $a$ variability, suggesting that the intrusions are important in promoting the local development of phytoplankton. The generation of slope water penetrations at this location may be triggered by the inshore excursion of the $100 \mathrm{~m}$ isobath, which appears to steer the Malvinas Current waters over the outer shelf.
\end{abstract}

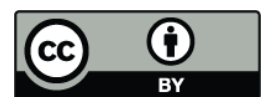

Correspondence to: A. R. Piola (apiola@hidro.gov.ar)

\section{Introduction}

Continental shelf-open ocean interactions lead to the exchange of mass, water properties and momentum (Loder et al., 1998), and may be important in the maintenance of the shelf ecosystems and carbon fluxes to the deep ocean. These exchanges are important because continental shelves constitute one of the most biogeochemically active areas of the biosphere (Borges et al., 2005) and are net sinks of substantial amounts of carbon (Muller-Karger et al., 2005). Thus, it is necessary to identify regions of enhanced shelf-deep ocean interactions and to understand the factors that control these exchanges and their variability.

South of about $40^{\circ} \mathrm{S}$ the wide continental shelf off southeastern South America presents thermohaline characteristics distinct from the adjacent deep ocean waters (Fig. 1). The shelf is occupied by diluted Subantarctic waters with salinity $(S)$ lower than 33.9. From 40 to $50^{\circ} \mathrm{S}$ the seasonal surface temperature variations are larger than $7^{\circ} \mathrm{C}$ (Podestá et al., 1991; Rivas, 1994) but salinity variations are relatively small because continental runoff from Patagonia (Vörösmarty et al., 1996) and evaporation-precipitation imbalance (Hoflich, 1984) are low. The injection of fresh water from the Río de la Plata near $34^{\circ} \mathrm{S}$ creates a low salinity region $(S<32)$ which presents large seasonal displacements from $38^{\circ} \mathrm{S}$ to about $26^{\circ} \mathrm{S}$ (Piola et al., 2000, 2005). The Malvinas Current (MC) flows northward along the continental shelf break, carrying cold, fresh $(S \sim 34)$ and nutrient rich subantarctic waters derived from the northern Drake Passage to about $38^{\circ} \mathrm{S}$

Published by Copernicus Publications on behalf of the European Geosciences Union. 

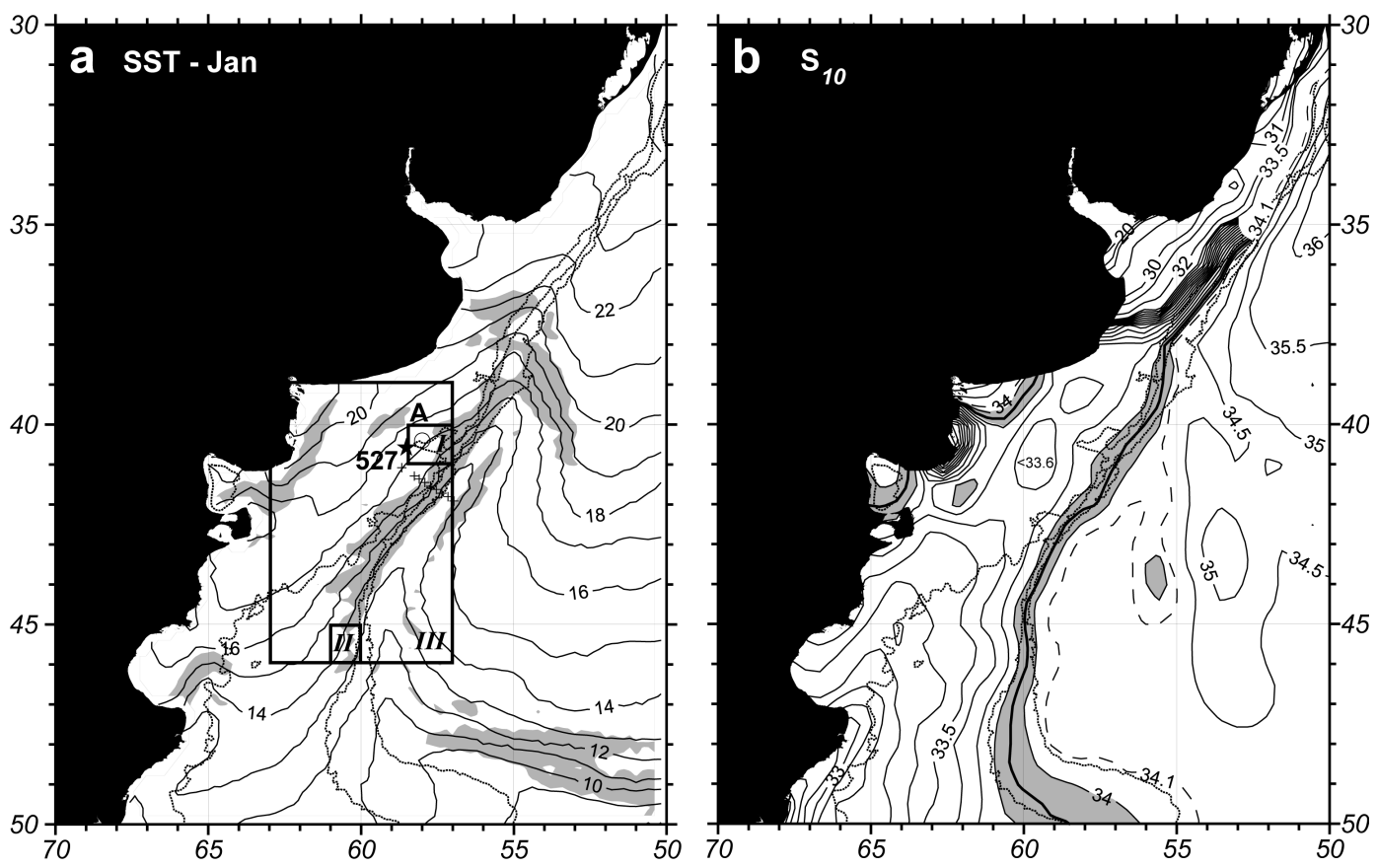

Fig. 1. (a) Mean January distribution of sea surface temperature based on 15 years of satellite data (1985-1999). Contour interval is $1^{\circ} \mathrm{C}$. Site A is indicated by an open circle, regions I, II and III are indicated by black rectangles. Also shown are the locations of the hydrographic section shown in Fig. $2(+)$, and station $527(\star)$. (b) Climatological salinity distribution at $10 \mathrm{~m}$ depth. Contour intervals for S10>32.5 over the continental shelf are 0.1 , and offshore 0.5 except when indicated. The grey shadings indicate the regions where the horizontal temperature gradient is larger than $0.018^{\circ} \mathrm{C} / \mathrm{km}$ in (a) and the $10 \mathrm{~m}$ salinities are within the 33.8-34 range in (b). The dotted lines in both panels indicate the 100,200 and $1000 \mathrm{~m}$ isobaths from GEBCO.

(Piola and Gordon, 1989; Peterson, 1992), where it collides with the southward flowing Brazil Current. Both currents veer offshore with the MC describing a sharp cyclonic loop, form an intense thermohaline front (Gordon, 1981; Olson et al., 1988) and create a region of strong mesoscale variability (Chelton et al., 1990; Goni and Wainer, 2001), referred to as the Brazil/Malvinas Confluence (Gordon and Greengrove, 1986). From austral spring to fall the Patagonian shelf and MC waters form a moderate sea surface temperature front $\left(>0.1^{\circ} \mathrm{C} \mathrm{km}^{-1}\right)$ which closely follows the $300 \mathrm{~m}$ isobath (Saraceno et al., 2004). Recent studies show that the shelf break front is frequently arranged as a series of narrow along shelf break bands, which appear to be steered by the bottom topography (Franco et al., 2008). The shelf-open ocean transition is also characterized by a salinity front extending from the sea surface to the bottom at the offshore edge of the continental shelf (Romero et al., 2006).

North of the Río de la Plata estuary $\left(\sim 34^{\circ} \mathrm{S}\right)$, where the continental shelf is narrow $(\sim 100 \mathrm{~km})$, the mean flow, shelf break eddies and small-scale mixing lead to an active exchange between Brazil Current and shelf waters (Soares and Möller, 2001; Souza and Robinson, 2004; Franco et al., 2005). Similarly, satellite color and sea surface temperature (SST) data reveal substantial eddy variability along the western edge of the MC south of $50^{\circ} \mathrm{S}$ (Glorioso et al., 2005), which suggests an active exchange with the outer continental shelf associated with mesoscale eddies. However, observations and models suggest relatively low eddy energy along the path of the MC (Goni and Wainer, 2001; Penduff et al., 2001; Palma et al., 2008; Oliveria et al., 2009). Thus, shelf open-ocean interactions between the MC and the outer shelf off northern Patagonia do not appear to be dominated by mesoscale eddies, as further north. This portion of the slope region presents intense chlorophyll blooms (Podestá, 1997; Longhurst, 1998; Saraceno et al., 2005; Romero et al., 2006; Signorini et al., 2006) and is important for the life cycle of a variety of species throughout the water column and in the benthic domains (Podestá, 1989; Bertolotti et al., 1996; Sanchez and Ciechomski, 1995; Rodhouse et al., 2001; Acha et al., 2004; Bogazzi et al., 2005). It has recently been suggested that downstream divergence of slope currents flowing in the direction of coastal waves, such as the Malvinas Current, caused by bottom friction and lateral diffusion, is compensated by upwelling near the shelf break (Matano and Palma, 2008). Shelf break upwelling may be responsible for the extended chlorophyll- $a$ maximum observed along the shelf break front (Romero et al., 2006). Based on the analysis of satellite derived SST and chlorophyll data, satellite tracked surface drifters, and hydrographic data, in this article we present evidence of previously undocumented 
slope water intrusions onto the continental shelf near $41^{\circ} \mathrm{S}$. As will be shown later, these intrusions contribute to the development of phytoplankton blooms over the outer Patagonia continental shelf. The data are described in Sect. 2 and a brief description of the hydrographic characteristics at the shelf break is provided in Sect. 3. Slope water intrusions are described in Sect. 4 and the discussion and conclusions are given in Sects. 5 and 6, respectively.

\section{Data and methods}

This study combines hydrographic data and surface drifters from the southwest South Atlantic continental shelf and slope, and SST and chlorophyll-a (Csat) data. The hydrographic data were obtained from holdings at the Argentine Oceanographic Data Center (http://www.hidro.gov.ar/ ceado/ceado.asp) and at Instituto Nacional de Investigación y Desarrollo Pesquero (Argentina, www.inidep.edu.ar). The satellite tracked surface drifters are WOCE-Surface Velocity Program type, drogued at $15 \mathrm{~m}$ depth, designed to follow the water to within $\pm .013 \mathrm{~m} \mathrm{~s}^{-1}$ in $10 \mathrm{~m} \mathrm{~s}^{-1}$ winds (Niiler et al., 1995). The original position data have been quality controlled and optimally interpolated to uniform six-hour interval trajectories (Hansen and Poulain, 1996). The data are available at NOAA Atlantic Oceanographic and Meteorological Laboratory (AOML, http://www.aoml.noaa.gov/ phod/index.php). Only drogued drifters are used. The 19851999 SST data, provided by the Rosenstiel School of Atmospheric Sciences (University of Miami), are derived from NOAA satellites processed in $4 \mathrm{~km}$ resolution Global Area Coverage and re-processed to declouded, 2-day means of $18 \mathrm{~km}$ resolution following the procedures described by Mariano and Brown (1992). The satellite color images of Csat concentration are Level 3, monthly mean Standard Mapped Images of $9 \mathrm{~km}$ resolution derived from the Sea-viewing Wide Field-of-view Sensor (SeaWiFS) for the period 19982007, provided by NASA/Goddard Space Flight Center (see O'Reilly et al., 2000).

SST variability is dominated by the annual cycle, which is not the focus of this study. Thus, to remove the seasonal variability at each grid point the annual cycle was first estimated as the sum of sine and cosine terms representing the annual and semi-annual periods (see Podestá et al., 1991; Martínez Avellaneda, 2005). The non-seasonal SST variability (SSTa) was then determined by subtracting the annual cycle from the observed SST. To determine the spatial pattern of non seasonal SST variability we carried out an empirical orthogonal function (EOF) analysis of SSTa (see Preisendorfer, 1988). The EOF is carried out on the spatial domain (e.g. S-EOF).

\section{The thermohaline distributions at the shelf break}

The salinity distribution at $10 \mathrm{~m}$ depth is used to describe the water mass structure in the upper layer. We chose the $10 \mathrm{~m}$ level to avoid near-surface salinity errors frequently present in quasi-continuous conductivity-temperature-depth instruments. The climatology is based on 16498 hydrographic stations, mostly collected after 1960 . The mid shelf is occupied by relatively fresh waters $(S<33.6)$, which can be traced southward to the coastal waters south of Tierra del Fuego and the Strait of Magellan (Brandhorst and Castello, 1971; Guerrero and Piola, 1997). South of $37^{\circ} \mathrm{S}$ the outer continental shelf is bounded by relatively colder and saltier "pure" subantarctic waters advected northward by the MC (Fig. 1). In the climatological salinity distribution at $10 \mathrm{~m}$ depth the transition from Subantarctic Shelf Water to Subantarctic Surface Water is depicted by the 33.8-33.9 isohalines, which, on average, are located just offshore of the $200 \mathrm{~m}$ isobath. Figure $1 \mathrm{~b}$ also suggests that the cross shelf salinity gradient, which characterizes the shelf break front, increases north of $47^{\circ} \mathrm{S}(\sim 0.3 / 100 \mathrm{~km})$, where the steepness of the bottom slope also increases considerably, allowing the core of the MC to approach the outer shelf. The salinity gradient again decreases slightly between 40 and $43^{\circ} \mathrm{S}$ (Fig. 1b). The 33.8-33.9 subsurface salinity range is also located close to the region of enhanced surface temperature gradient north of about $45^{\circ} \mathrm{S}$ (Fig. 1a).

The cross shelf thermohaline structure at the shelf break near $41^{\circ} \mathrm{S}$, as observed in March 1994 is illustrated in Fig. 2 (station locations are shown in Fig. 1a). The cross shelf vertical section is characterized by a sharp seasonal thermocline over the shelf, which weakens offshore due to the outcrop of the near surface isotherms near stations 34 and 35 . The outcrop of the seasonal thermocline creates a cross-shore temperature front at the western edge of the MC. The shelf break front is also characterized by the offshore salinity increase extending from the sea surface to the bottom, with $S<33.7-33.8$ over the shelf and $S>34$ on the MC core. The salinity front, centered close to the 33.9 isohaline, intersects the bottom at the shelf break and rises offshore with a mean slope of $3 \times 10^{-3}$ (Fig. 2b), similar to the shelf break front structure at the seaward edge of the Mid-Atlantic Bight south of New England (Beardsley and Flagg, 1976). Though the temperature distribution suggests an intrusion of cold slope waters into the shelf lower layer $\left(T<7^{\circ} \mathrm{C}\right)$, the outer shelf bottom waters are 0.35 fresher than the slope water, also inducing a weak cross-shelf density gradient in the bottom layer (Fig. 2). The cross shelf salinity contrast throughout the water column suggests limited exchange between outer shelf and slope waters across the shelf break front.

The shelf-open ocean transition is further illustrated by a T-S diagram of selected stations (Fig. 3). On average, the shelf waters are fresher than 33.80 and present minor seasonal and vertical salinity variations. The densest shelf waters are less dense than $26.5 \mathrm{~kg} \mathrm{~m}^{-3}$, and present relatively uniform near bottom properties throughout the year (not shown). Vertical salinity stratification increases towards the shelf break, where mixtures of cold-salty $\left(\sim 6^{\circ} \mathrm{C}\right.$ $S>34$ ) slope water intrude near the bottom (e.g. station 34 , 

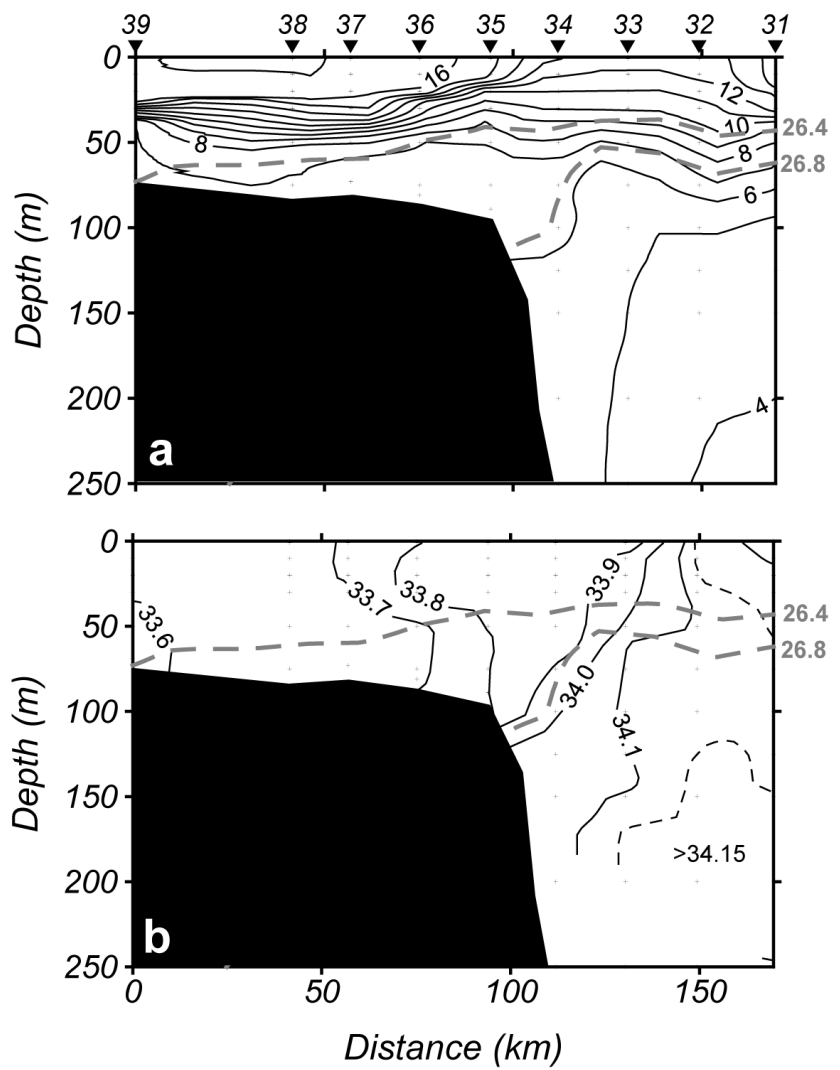

Fig. 2. Temperature (a) and salinity (b) sections across the Patagonia shelf break at $42^{\circ} \mathrm{S}$ collected in March 1994. The station locations are shown in Fig. 1a. The grey dashed lines are $\gamma$ contours.

Figs. 2 and 3). Further offshore, station 32 presents a tight nearly isohaline distribution of waters warmer than $3{ }^{\circ} \mathrm{C}$ and a sharp slope change in the T-S diagram at about $2.5^{\circ} \mathrm{C}-34.1$. These T-S characteristics within the core of the cyclonic loop formed by the MC and its southward return can be traced upstream to the Drake Passage (Piola and Gordon, 1989).

\section{Results: a case for slope water intrusions}

\subsection{Sea surface temperature signature}

The northward flowing MC creates a wedge of cold waters along the western edge of the Argentine Basin. Between 46 and $38^{\circ} \mathrm{S}$ the west edge of the MC, as determined by the location of the high SST gradient band separating warm shelf waters from the MC, closely follows the $300 \mathrm{~m}$ isobath (Saraceno et al., 2004). Inspection of the 2-day SST and SSTa composites in the period 1985-1999 reveals a total of 56 onshore isotherm inflections and negative anomalies near the shelf break between 38.5 and $46^{\circ} \mathrm{S}$. About $50 \%$ of these events occur between 40 and $41^{\circ} \mathrm{S}$, where anomalies range between -0.5 and $-3^{\circ} \mathrm{C}$ and persisted between 4 and 32 days. Figure 4a depicts the SST distribution on 17 March

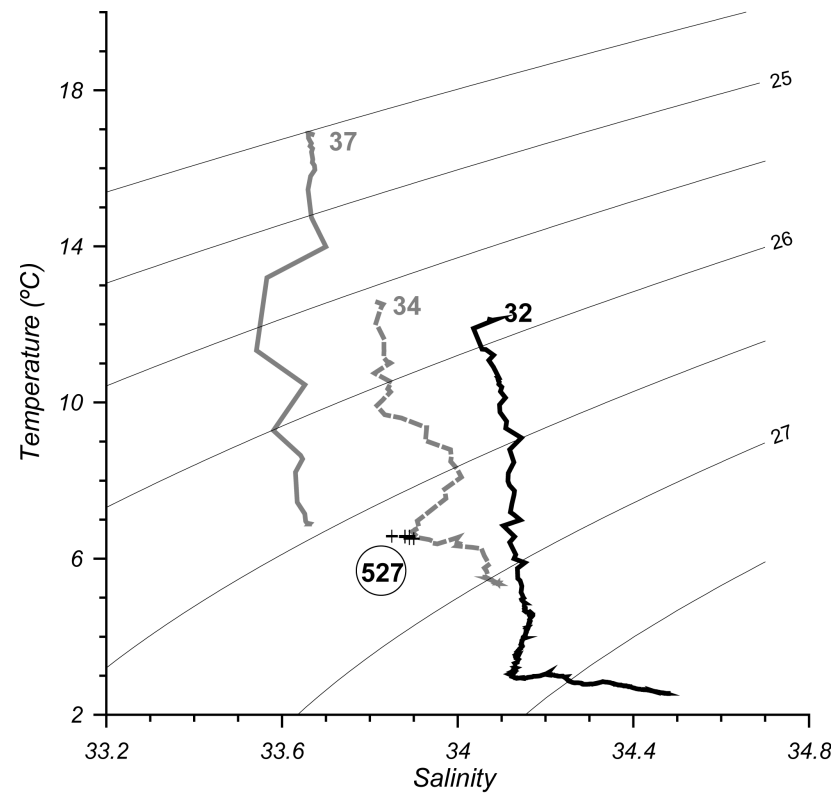

Fig. 3. Temperature-salinity diagrams of selected stations occupied in the outer shelf (37), slope water (34) and offshore waters (32) in March 1994 (see Fig. 2). Station 527 was occupied in July 1996, $125 \mathrm{~km}$ inshore from the $200 \mathrm{~m}$ isobath. The thin lines are constant $\gamma\left(\mathrm{kg} \mathrm{m}^{-3}\right)$.

1986. The northward flow of the Malvinas Current along the continental slope creates the sharp temperature minimum located east of the $200 \mathrm{~m}$ isobath, which extends to about $37^{\circ} \mathrm{S}$. Figure $4 \mathrm{~b}$ illustrates the SSTa for the same day. Between approximately 40 and $42^{\circ} \mathrm{S}$, the $15^{\circ} \mathrm{C}$ isotherm deflects westward about $100 \mathrm{~km}$, suggesting the intrusion of cold slope water over the outer shelf. The inset in Fig. 4a presents the evolution of the $15^{\circ} \mathrm{C}$ isotherm from 27 February to 19 March 1986. Sea surface temperature in the outer shelf at $40.5^{\circ} \mathrm{S}$ decreased $3.8^{\circ} \mathrm{C}$ from 23 February to 19 March 1986 (see inset in Fig. 4b). The amplitude of seasonal variations in the outer shelf south of $40^{\circ} \mathrm{S}$ is $\sim 10^{\circ} \mathrm{C}$, with highest SST occurring in early February (Podestá et al., 1991; Martínez Avellaneda, 2005). To determine to what extent the temperature decrease observed at site $\mathrm{A}\left(40.5^{\circ} \mathrm{S}-58^{\circ} \mathrm{W}\right)$ is due to seasonal cooling the inset in Fig. $4 \mathrm{~b}$ also presents the SSTa at that location. SSTa at site A presents temperature anomalies closely following the observed SST, and a decrease of $2.6^{\circ} \mathrm{C}$ between late February and mid March 1986. Thus, about $70 \%$ of the drop in SST observed at site A does not seem to be a result of the mean seasonal cooling. During the cooling period, the net heat flux through the sea surface at site A, based on the data of Yu and Weller (2007), is $61 \pm 74 \mathrm{~W} \mathrm{~m}^{-2}$ into the ocean. In the absence of mixing and advection, during the 25 days of observed cooling the sea-air heat flux would have lead to an average warming of $\sim 1^{\circ} \mathrm{C}$ if the heat is distributed over the upper $30 \mathrm{~m}$ of the water column. As the heat exchange with the atmosphere would act to 

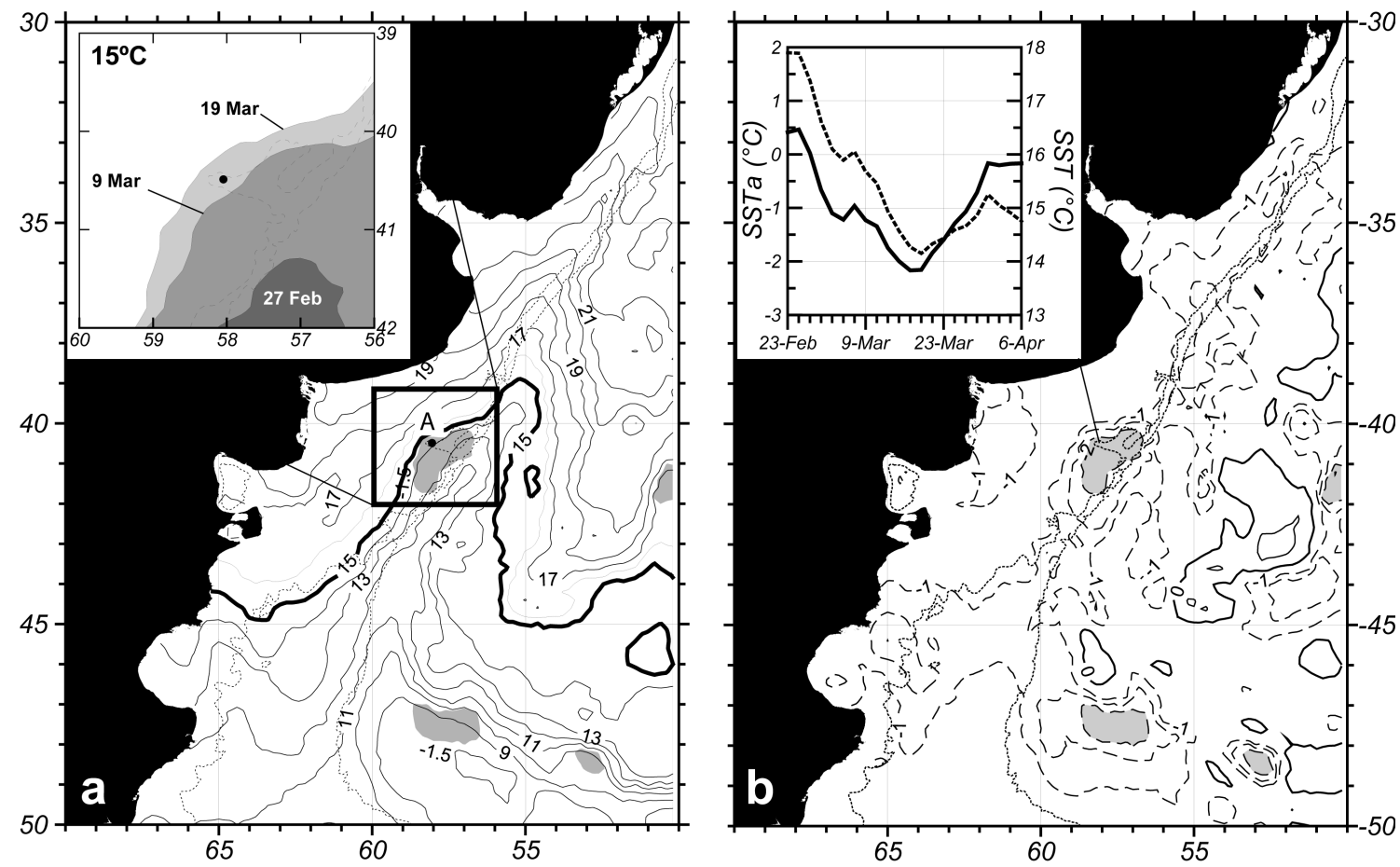

Fig. 4. Distribution of (a) satellite derived SST and (b) SST anomalies on 17 March 1986, both in ${ }^{\circ} \mathrm{C}$. The heavy contour in (a) is the $15^{\circ} \mathrm{C}$ isotherm and the shaded contours in (b) are anomalies lower than $-2{ }^{\circ} \mathrm{C}$, also reproduced in (a). The dotted lines in both panels are the 100 and $200 \mathrm{~m}$ isobaths from GEBCO. The location of site $\mathrm{A}(\bullet)$ is indicated in (a). The inset in (a) shows the evolution of the $15^{\circ} \mathrm{C}$ isotherm on 27 February, 9 and 19 March 1986, with waters colder than $15^{\circ} \mathrm{C}$ shaded. The inset in (b) shows the SST $\left({ }^{\circ} \mathrm{C}\right.$, dotted line) and SSTa $\left({ }^{\circ} \mathrm{C}\right.$, heavy line) time series at A (see text).

warm rather than cool the upper layer, an inshore intrusion of slope waters seems to be the most plausible explanation for the temperature decrease observed in March 1986 (Fig. 4).

\subsection{Non seasonal sea surface temperature variability}

To determine the spatial pattern of non seasonal SST variability we carried out an empirical orthogonal function (EOF) analysis of SSTa. The first EOF, which explains $29 \%$ of the non seasonal SST variance, displays two centers of action (Fig. 5). One is centered close to $40.5^{\circ} \mathrm{S} 53^{\circ} \mathrm{W}$ at the location of highest sea surface height variability $(>35 \mathrm{~cm}$, Goni and Wainer, 2001; Palma et al., 2008) and highest eddy kinetic energy as derived from altimetry $\left(\sim 1500 \mathrm{~cm}^{2} \mathrm{~s}^{-2}\right.$, Volkov and $\mathrm{Fu}, 2008)$ and surface drifters $\left(>2000 \mathrm{~cm}^{2} \mathrm{~s}^{-2}\right.$, Oliveira et al., 2009), and is associated with eddies and meanders at the Brazil/Malvinas Confluence. The first EOF also presents a center of action at the outer shelf near $41^{\circ} \mathrm{S}-$ $58^{\circ} \mathrm{W}$. This is the location where most of the cooling events are observed over the northern Patagonia continental shelf (Fig. 5).

Local cooling events at site A can be due to a variety of processes and time scales. The most intense events over the continental shelf are associated with the passage of atmospheric fronts, which can cause sharp temperature drops $\left(\sim 3{ }^{\circ} \mathrm{C}\right.$ in $\left.30 \mathrm{~h}\right)$ in the upper layer (Rivas and Piola, 2002). These cooling events are of a regional nature and extend over the entire shelf in a few days. To quantify the events that are not associated with large scale regional changes we calculated the difference between SSTa at site A and the SSTa averaged over region III, limited by $39-46^{\circ} \mathrm{S}$ and $57-63^{\circ} \mathrm{W}$ (hereafter referred to as $\Delta \mathrm{SST}$, see Fig. 1a). This region includes both, oceanic and shelf domains, but excludes the region of high SST variability around the Brazil/Malvinas Confluence. The time series of $\Delta$ SSTa presents several minima associated with sharp localized cooling at site A relative to the surroundings (Fig. 6). The rate of the temperature change, the magnitude of the anomaly and the estimated heat exchanged with the atmosphere (Yu and Weller, 2007; Yu et al., 2008) of the most intense events $\left(\Delta \mathrm{SSTa}<-1.5^{\circ} \mathrm{C}\right)$ are given in Table 1. The sea-air heat flux is averaged over three days prior to the lowest $\triangle \mathrm{SST}$. During seven of these localized cooling periods the estimated heat flux through the sea surface was positive (into the ocean, Table 1). The only event which was preceded by heat loss to the atmosphere ( 25 May 1987) is actually the one associated with the less intense non-seasonal cooling at site A (SSTa $=-0.66^{\circ} \mathrm{C}$ in six days, Table 1). Thus, it seems unlikely that sea-air heat exchanges can explain the intense temperature drops observed at site A relative to the surrounding area. 
Table 1. Characteristics of the most intense SST events $\left(\triangle \mathrm{SST} a<-1.5^{\circ} \mathrm{C}\right)$.

\begin{tabular}{ccccc}
\hline Date & $\begin{array}{c}\mathrm{SST} \text { drop }\left({ }^{\circ} \mathrm{C}\right) \\
\text { 6 days }\end{array}$ & $\begin{array}{c}\mathrm{SST} \text { drop }\left({ }^{\circ} \mathrm{C}\right) \\
\text { 10 days }\end{array}$ & $\begin{array}{c}\Delta \mathrm{SSTa} \\
\left({ }^{\circ} \mathrm{C}\right)\end{array}$ & $\begin{array}{c}Q \\
\left(\mathrm{~W} \mathrm{~m}^{-2}\right)\end{array}$ \\
\hline 16 Mar 1987 & -1.90 & -3.62 & -1.70 & 69 \\
25 May 1987 & -0.66 & -0.97 & -1.74 & -80 \\
1 Nov 1987 & -1.53 & -1.80 & -1.64 & 157 \\
29 Feb 1988 & -1.49 & -0.41 & -2.23 & 175 \\
15 Apr 1988 & -1.12 & -2.90 & -1.58 & 14 \\
1 Mar 1991 & -1.07 & -1.68 & -1.80 & 145 \\
10 Dec 1994 & -1.49 & -1.41 & -1.56 & 271 \\
13 Feb 1996 & -1.88 & -2.46 & -1.55 & 37 \\
\hline
\end{tabular}

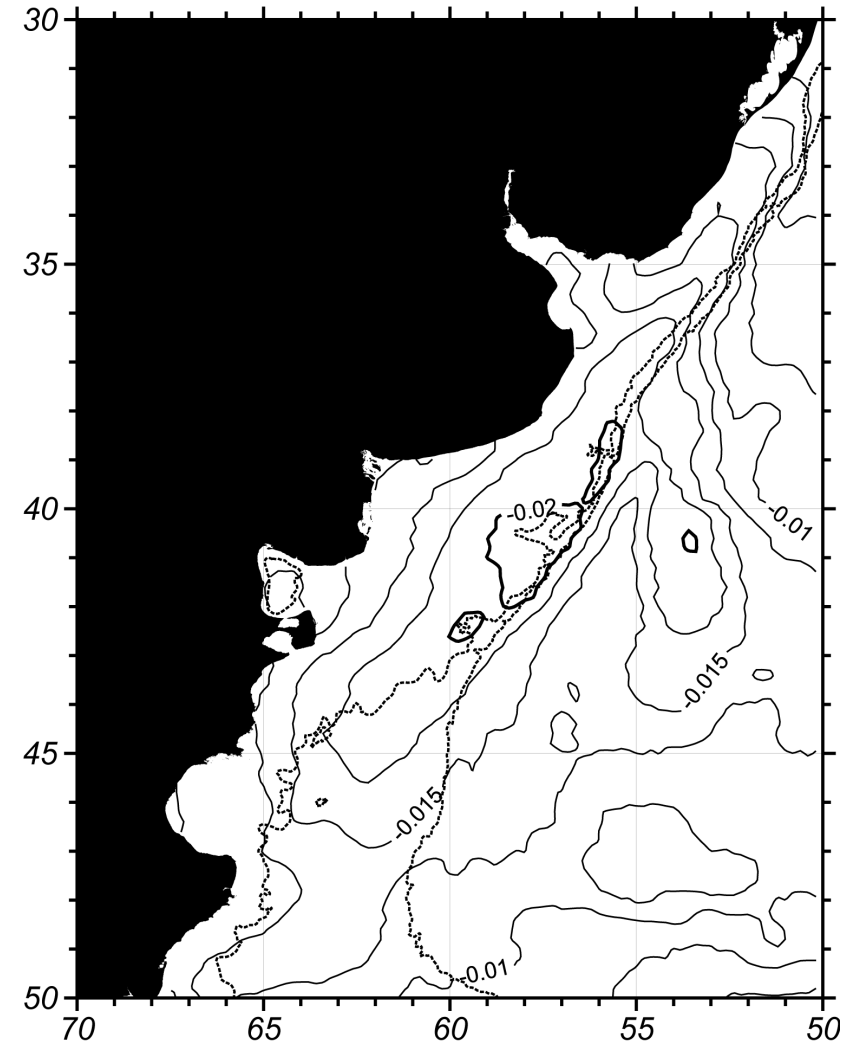

Fig. 5. First mode of the empirical orthogonal function of SST variability (SSTa) estimated over the period 1985-1999. The heavy contour indicates the center of action of non-seasonal SST variability. The dotted lines indicate the 100 and $200 \mathrm{~m}$ isobaths from GEBCO.

The most intense events in terms of SST occur from mid austral spring (November) to mid fall (May, see Table 1), while the less intense events, with $|\Delta \mathrm{SSTa}|<$ $1{ }^{\circ} \mathrm{C}$ throughout the record length, occur in austral winter (July-September). A plausible explanation for the apparent seasonal modulation of high-frequency SSTa is the seasonal variation in the magnitude of the temperature gradient $(\partial T / \partial x)$ across the shelf break front. The SST gradient is highest in austral summer and lowest in winter (Saraceno et al., 2004; Franco et al., 2008; Rivas and Pisoni, 2010).

The cooling of the upper layer observed in the outer shelf at site A suggests either more intense westward advection of relatively cold slope water, or localized upwelling of subthermocline waters. In the following analysis we present evidence supporting the hypothesis of enhanced slope water intrusions at this location. The analysis also documents winter events which, in terms of westward penetration of slope water, appear to be at least as intense as the ones reported above based on the observed SST variability.

\subsection{Hydrographic observations}

The thermohaline structure across the shelf break front is characterized by an offshore temperature decrease and salinity increase. Therefore, onshore intrusions of slope waters should lead to negative SST anomalies, as described above, and also to high salinity $(S>33.9$, Fig. $1 \mathrm{~b})$. In this section we analyze hydrographic data to search for high salinity anomalies in the vicinity of site A.

To depict the water mass structure of the westward intrusions onto the continental shelf we present data taken in austral winter 1996. From 13 July to 14 August 1996 the R/V Dr. E. Holmberg occupied 123 CTD stations between 44 and $35^{\circ} \mathrm{S}$ (Fig. 7). At $10 \mathrm{~m}$ depth the $6.5^{\circ} \mathrm{C}$ isotherm and 33.9 isohaline closely follow the $200 \mathrm{~m}$ isobath, marking the outer shelf-slope water transition. Near $41^{\circ} \mathrm{S}$ however, both, temperature and salinity distributions present inshore isopleth deflections of about $100 \mathrm{~km}$. The hydrographic stations in this region were occupied on 26 July 1996. The event caused the low SST signal between 40 and $42^{\circ} \mathrm{S}$, apparent from late April to late July 1996. Since during winter the cross-shelfbreak SST gradients and the thermal stratification are weak, the July 1996 event was moderate in terms of $\triangle \mathrm{SSTa}$, with lowest values reaching $-0.6^{\circ} \mathrm{C}$ (Fig. 6).

At $10 \mathrm{~m}$ depth station 527, occupied about $120 \mathrm{~km}$ inshore of the $200 \mathrm{~m}$ isobath (see Fig. 1a for location), presents thermohaline characteristics typical of the slope water: $6.58^{\circ} \mathrm{C}$ 


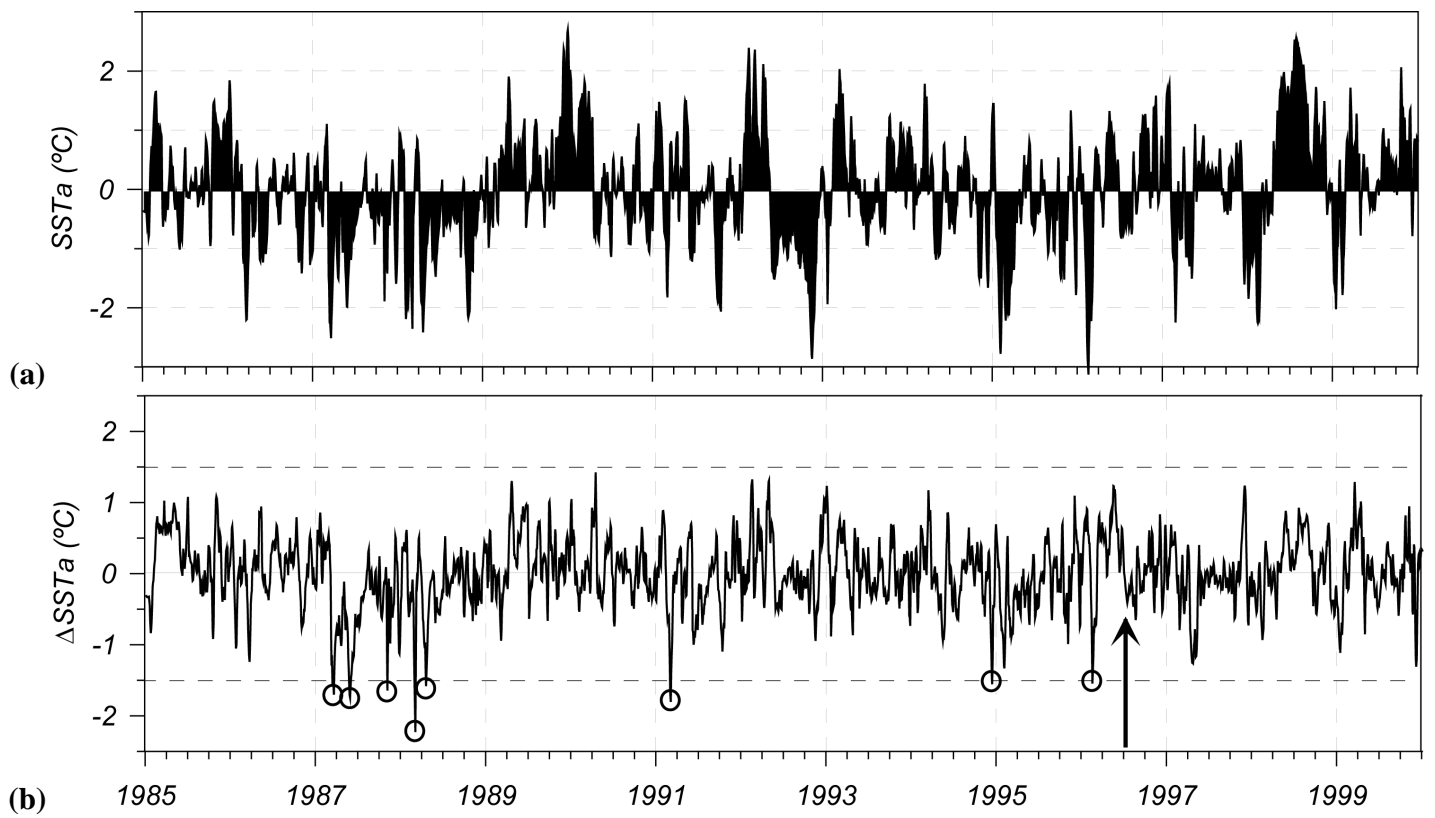

Fig. 6. Time series of SSTa at site A (a) and of SSTa difference between site A and region III (b), see Fig. 1 and text. The open circles indicate events when $\triangle \mathrm{SSTa}<-1.5$. The latter is an indication of the non seasonal SST variability at site A relative to regional SST anomalies. The arrow indicates the time of occupation of the R/V Holmberg cruise.

and 33.8, about 0.2 saltier than shelf waters (Fig. 3). The water column at station 527, which reached within $2 \mathrm{~m}$ of the bottom, is virtually homogeneous, further revealing that in winter the surface inshore intrusions extend vertically throughout the water column. This observation is also confirmed by the near bottom temperature and salinity distributions in July 1996 (Fig. 7c, d), which display inshore excursions of isotherms and isohalines near $41^{\circ} \mathrm{S}$, similar to the surface pattern. Thus, the in situ data collected in July 1996 show that the outer shelf cooling in the upper layer is also associated with relatively high surface salinity, and that these anomalies extend throughout the water column.

Additional evidence for the slope water intrusions near $41^{\circ} \mathrm{S}$, is derived from the analysis of historical hydrographic data. We analyzed data from 21 cruises collected between 1981 and 2004 within the area bounded by $40-41^{\circ} \mathrm{S}$ and 57-58.5 $5^{\circ} \mathrm{W}$ (region I in Fig. 1). To exclude stations taken outside from the continental shelf, only stations occupied at bottom depth shallower than $90 \mathrm{~m}$ are considered. To characterize the waters below the seasonal thermocline, salinity data at each station were vertically averaged within the 60 $90 \mathrm{~m}$ depth range. The relative distribution of salinity binned in 0.05 class intervals suggests a relatively wide variability, with a main salinity mode centered on 33.75-33.8 (Fig. 8). The main salinity mode is representative of the most abundant variety of Subantarctic Shelf Water (Piola et al., 2000). In addition, a secondary mode $(S>33.95)$ containing only about $10 \%$ of the observations is apparent. A bimodal salinity distribution is also observed in the upper layer $(0-20 \mathrm{~m})$, with the salinity modes 0.05 fresher than in the lower layer (not shown). Since the hydrographic data are not collected at regular time intervals, no conclusion can be drawn as to the frequency of the slope water intrusions. However, the salinity histograms within both layers present the expected distribution for intermittent high salinity events. Perhaps a more important question to ask is whether similar bimodal distributions are present elsewhere. To this end, a similar analysis was carried out at the shelf break further south, within the region bounded by $44-45^{\circ} \mathrm{S}$ and $60-61^{\circ} \mathrm{W}$ (region II in Fig. 1a), which also presents a substantial number of observations near the shelf break. Data from 12 hydrographic cruises taken between 1983 and 2003 are available in region II. We observe two distinct results from region I (Fig. 8): first, the distribution is not bimodal; second, the highest salinities observed in region II are 0.05 fresher $(<33.95)$. Thus, the salinity variability in region I supports the hypothesis that slope waters are present at that location, and not in region II.

\subsection{Surface chlorophyll- $a$}

The Malvinas Current is thought to be a significant nutrient source for the relatively intense chlorophyll maxima observed in austral spring and summer along the Patagonia shelf break (e.g. Carreto et al., 1995; Podestá, 1997; Romero et al., 2006). Inshore intrusions of slope waters are therefore a potential source for enhanced nutrient enrichment over the shelf. In this region, cloud cover prevents the use of reliable 

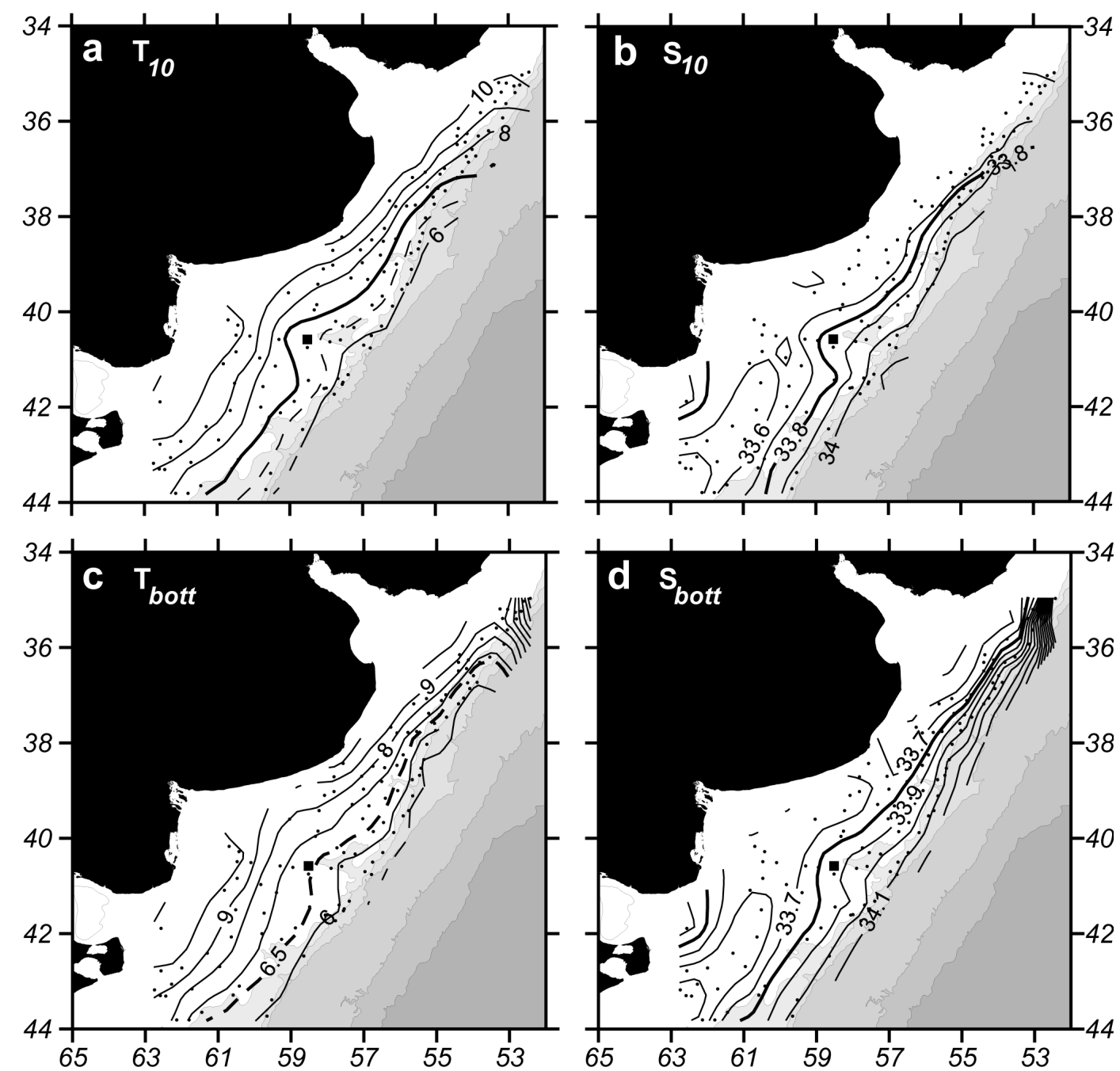

Fig. 7. Distributions of temperature (a and c) and salinity (b and d) at $10 \mathrm{~m}$ depth (upper panels) and bottom (lower panels), based on

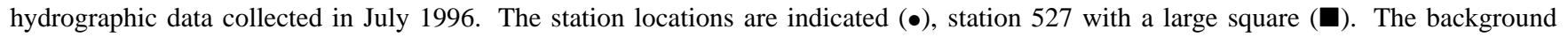
shading are the 100, 200,1000, 3000 and $5000 \mathrm{~m}$ isobaths.

color data in time scales of a few days; we therefore analyze monthly mean images during the period 1998-2007. Inspection of the mean Csat distribution in January suggests an onshore extension of the high chlorophyll region associated with the shelf break front $\left(\right.$ Csat $\left.>2.0 \mathrm{mg} \mathrm{m}^{-3}\right)$ near $41^{\circ} \mathrm{S}$ (Fig. 9a). Moreover, the Csat maximum presents a local increase at around $41^{\circ} \mathrm{S}$, which extends downstream (northeastward) to about $39^{\circ} \mathrm{S}$, closely following the $200 \mathrm{~m}$ isobath. These patterns are in general agreement with the findings of Romero et al. (2006, their Fig. 2c). Since the variability of Csat over the shelf and slope is strongly coupled to the annual cycle (e.g. Garcia et al., 2004; Romero et al., 2006), to understand the nature of the spatial distribution of Csat variability we removed the seasonal variability by calculating anomalies (Csat $a$ ) relative to the 1998-2007 monthly means. The standard deviation of Csat $a$ is depicted in Fig. 9b. This pattern is similar to the first EOF mode of Csat $a$, which explains $23 \%$ of the non-seasonal variability (not shown). The highest standard deviation of Csat $a$ is found along the shelf break and in near coastal regions. These regions of high Csat concentration $\left(>2 \mathrm{mg} \mathrm{m}^{-3}\right)$ are associated with frontal areas in the mean January distribution (Fig. 9a, see also Romero et al., 2006), and the mouth of Río de la Plata near $35^{\circ} \mathrm{S}$. In addition, a high variability region is observed in the mid and outer shelf area between 41 and $38^{\circ} \mathrm{S}$. This region is colocated with the area where slope water intrusions have been identified based on the non-seasonal SST variability and hydrographic data. As suggested by the large Csat variability, we will discuss below the possible role of slope water intrusions on the development of phytoplankton blooms at this location. 
Table 2. Intrusion characteristics from surface drifters.

\begin{tabular}{cccccc}
\hline Drifter ID & Entry date & Entry latitude $\left({ }^{\circ} \mathrm{S}\right)$ & Mean speed $\left(\mathrm{m} \mathrm{s}^{-1}\right)$ & Duration (days) & Exit latitude $\left({ }^{\circ} \mathrm{S}\right)$ \\
\hline 16617 & 3 Jul 1997 & 41.79 & 0.16 & 53 & 37.78 \\
25815 & 4 Jan 1998 & 41.78 & 0.20 & 41 & 37.49 \\
34012 & 14 Mar 2003 & 42.25 & 0.27 & 37 & 37.31 \\
$34035^{\mathrm{a}}$ & 14 Feb 2004 & 41.26 & 0.18 & 52 & 36.37 \\
54989 & 19 May 2006 & 41.30 & 0.18 & 20 & 39.14 \\
\hline
\end{tabular}

a Drifter 34035 described the cyclonic offshore turn on 9 March 2004 but rather than exiting the continental shelf it continued drifting northward along a mid-shelf path.

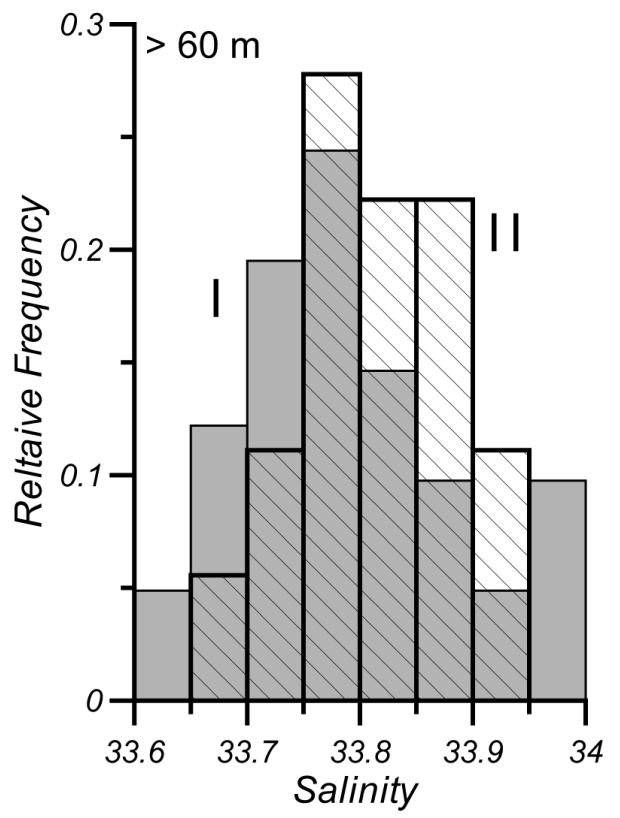

Fig. 8. Relative number of observations within 0.05 salinity class intervals for waters deeper than $60 \mathrm{~m}$ in the outer continental shelf in regions I (light grey) and II (hatched). See Fig. 1 for locations.

\subsection{Surface drifters}

WOCE surface velocity drifters are excellent indicators of the surface velocity field and are used here to illustrate the location and kinematic characteristics of the slope water intrusions onto the continental shelf near $41^{\circ} \mathrm{S}$. We used all drifter data available at AOML that were deployed in the western South Atlantic. The drifter trajectories along the continental shelf break and south of about $42^{\circ} \mathrm{S}$ are extremely smooth, and closely follow the isobaths along the continental shelf slope (Fig. 10). This is a result of the barotropic character of the MC, which is strongly steered by the bottom topography (Vivier and Provost, 1999; Saraceno et al., 2004). Inshore of the $2000 \mathrm{~m}$ isobath and south of around $39^{\circ} \mathrm{S}$ all drifters have a relatively strong northward component (Fig. 10; see also Oliveira et al., 2009). Of the 30 drifters moving northward along the western edge of the Argentine Basin, five entered the continental shelf near $41^{\circ} \mathrm{S}$ (color tracks in Fig. 10, Table 2). At no other latitude inshore intrusions are suggested by the drifter trajectories and the five drifters deployed within the continental shelf displaced offshore as they moved northward (e.g. 16617 and 34035, Fig. 10a). Such offshore component of the surface layer circulation is a response to the strong westerly winds as predicted by numerical models (e.g. Palma et al., 2008). After returning to the deep ocean, all drifters are embedded in a southward flow, either by the Brazil Current or within the Brazil/Malvinas Confluence. Drifters 25815 and 34012 were deployed close to the $200 \mathrm{~m}$ isobath and drifter 54989 in the mid-shelf region at $47^{\circ} \mathrm{S}$. All these drifters display a sharp anticyclonic turn near $41^{\circ} \mathrm{S}$ and displaced westward about $100-150 \mathrm{~km}$. After entering the shelf most drifters moved northward to about $40^{\circ} \mathrm{S}$ and turned back offshore to the outer shelf. Drifter 16617 entered the outer shelf in early July 1997 , a period relatively quiet in $\triangle$ SSTa at point A (Fig. 6), providing independent evidence that winter intrusions may be associated with a weak SST signal. This drifter crossed the $100 \mathrm{~m}$ isobath at $37.7^{\circ} \mathrm{S}$ after 55 days but continued moving northward along the shelf break and turned further offshore and southward near $34^{\circ} \mathrm{S}$. This is the northernmost latitude reached by any of the northward moving drifters along the western Argentine Basin. Drifter 34035, entered the shelf more abruptly at $41.48^{\circ} \mathrm{S}$ in mid February 2004 and later followed a similar path to 16617 but continued moving northward along the mid-shelf to about $37^{\circ} \mathrm{S}$, where it crossed the shelf break in the offshore direction 55 days later. Drifter 34012 presents a different trajectory from the rest of the intrusion drifters, it entered the shelf in mid March 2003 and, after describing the inshore loop it drifted northward in the mid shelf then along a near coastal path reaching about $90 \mathrm{~km}$ from shore at $38^{\circ} \mathrm{S}$. Further north, 34012 reached the shelf break again near $37^{\circ} \mathrm{S}$. The drifter data depict the path and possible northward extent of the slope water entering the shelf near $41^{\circ} \mathrm{S}$. Table 2 summarizes information on the entry date and latitude, drift velocity and duration of each of the intrusions as captured by these drifters. 

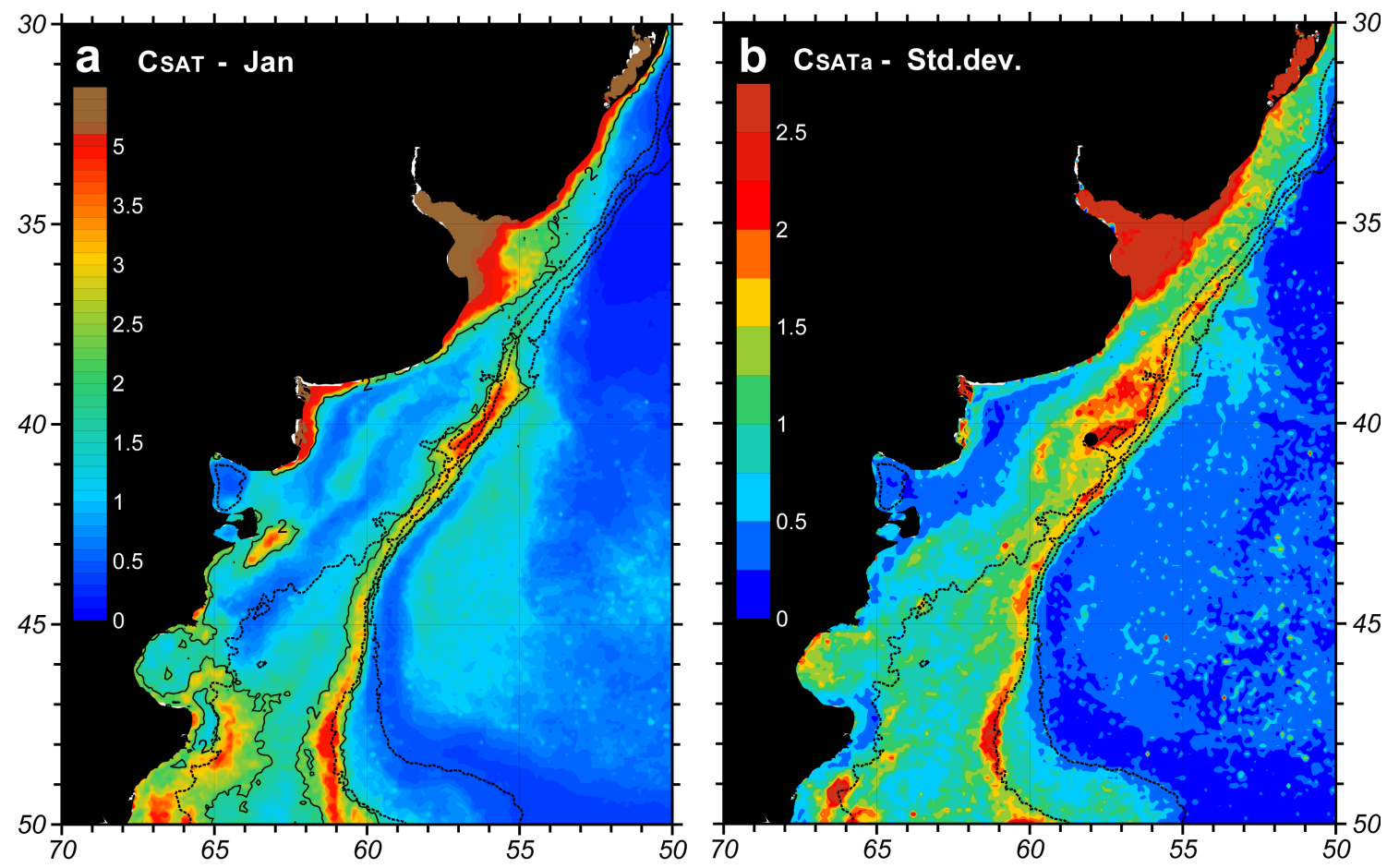

Fig. 9. (a) Mean January surface chlorophyll- $a$ distribution (1998-2007) based on SeaWiFS data (Csat). The solid line indicates the $2 \mathrm{mg} \mathrm{m}^{-3}$ contour. (b) Standard deviation of the record-length monthly anomalies (Csat $a$ ). The black dot in (b) is the position of site A (see Fig. 1). The dotted lines in both panels are the 100, 200 and $1000 \mathrm{~m}$ isobaths from GEBCO.

\section{Discussion}

\subsection{Impact of slope water intrusions}

Based on SeaWiFS derived chlorophyll- $a$, the Patagonia shelf break blooms typically reach values close to $10 \mathrm{mg} \mathrm{m}^{-3}$ (e.g. Romero et al., 2006, their Fig. 3). These high Csat concentrations have been verified by in-situ determinations (>11 $\mathrm{mg} \mathrm{m}^{-3}$, e.g. Garcia et al., 2008; Bianchi et al., 2009). Given the proper light and stratification conditions, inshore intrusions of nutrient-rich Malvinas Current waters may act to promote or enhance the growth of phytoplankton over the continental shelf. To a large extent, the non-seasonal Csat variability is interannual (e.g. Rivas et al., 2006; Romero et al., 2006). The 10-year (1998-2007) Csat time series over the Patagonia continental shelf presents the maximum intensity and spatial extension in spring 2003. Based on the combined analysis of SST, Csat, historical hydrographic data and outputs from a high resolution numerical model, Signorini et al. (2009) provided a detailed analysis of this event and discussed various possible mechanisms leading to the anomalous phytoplankton bloom. In November 2003 the Csat bloom extended throughout the mid and outer shelves with values higher than $3 \mathrm{mg} \mathrm{m}^{-3}$ and a sharp drop at the shelf break to Csat $<0.2 \mathrm{mg} \mathrm{m}^{-3}$ (Fig. 11a). Csat $a$ in November 2003 presented values higher than $25 \mathrm{mg} \mathrm{m}^{-3}$ centered around $40.3^{\circ} \mathrm{S}-57.7^{\circ} \mathrm{W}$ (Fig. 11b). Thus, the highest Csat $a$ observed in November 2003 is located in the same region where we observe the highest non-seasonal variability of SST. The numerical model outputs analyzed by Signorini et al. (2009, their Fig. 10a) suggest that at the time of the 2003 bloom the shelf circulation was characterized by a strong northeastward flow along the coast, and a sharp inshore deflection of slope waters near $41-42^{\circ} \mathrm{S}$. The latter resembles the slope water intrusions described above. However, their estimates of onshore nitrate flux based on the model temperature, a proxy for dissolved nitrate, and currents in the upper layer, did not present particularly high values during the austral spring of 2003, as expected for strong slope water intrusions. Given the extent of the Csat bloom observed in spring 2003 (the $10 \mathrm{mg} \mathrm{m}^{-3}$ contour extends from 43 to $36^{\circ} \mathrm{S}$, Fig. 11a) it seems unlikely that it could have been the response to a slope water intrusion of the scale suggested by the drifter trajectories $(\sim 100-150 \mathrm{~km})$. However, the Csat $a$ distribution clearly indicates that, whatever mechanism lead to the anomalous phytoplankton development over the northern Patagonia continental shelf, its effects were substantially enhanced near $40-41^{\circ} \mathrm{S}$, the region where the slope water intrusions are documented in this paper.

\subsection{Genesis of slope water intrusions}

The high SST and Csat variability observed in the outer shelf near $41^{\circ} \mathrm{S}$ suggest that the region is characterized by 

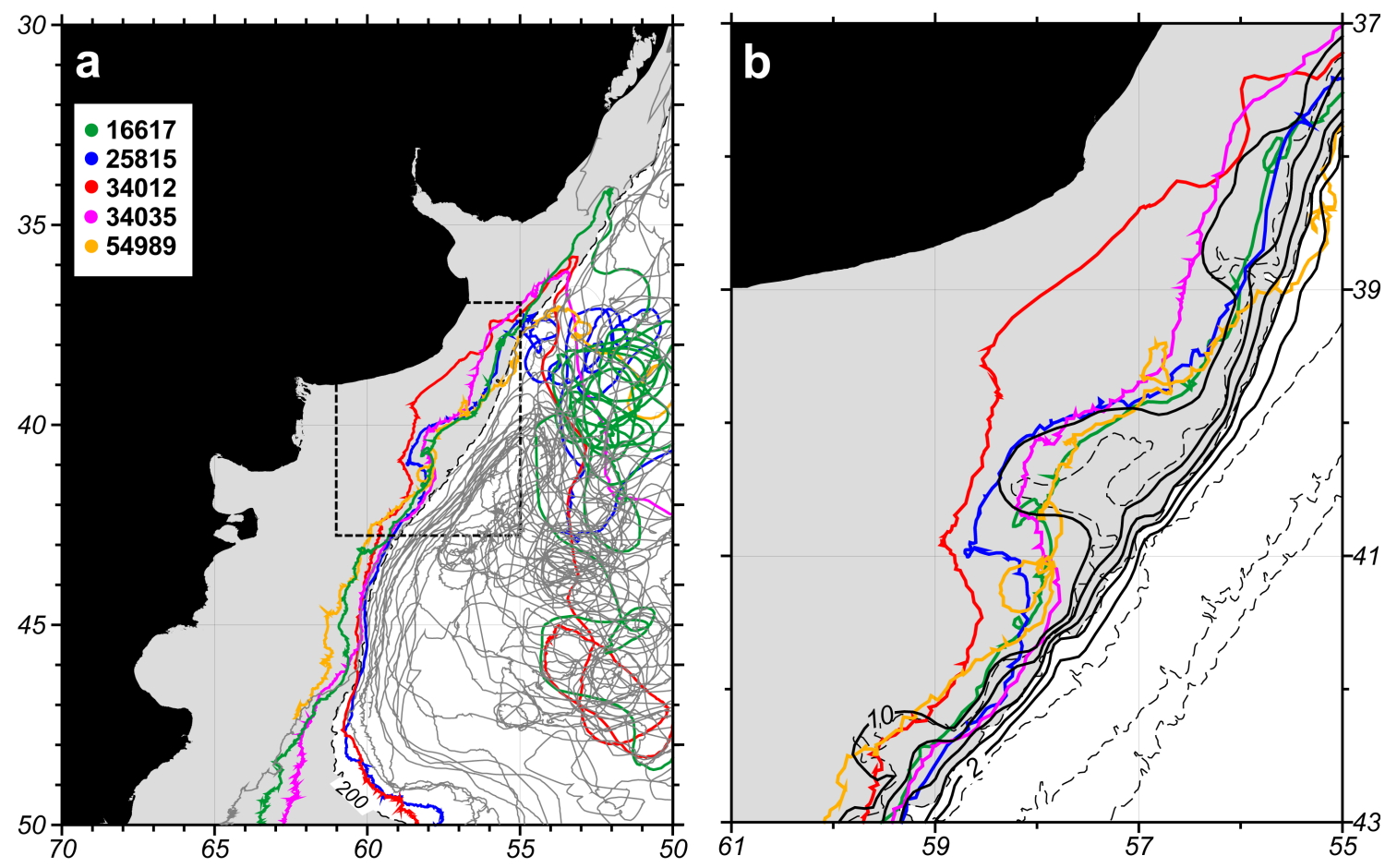

Fig. 10. Trajectories of WOCE surface drifters in the western South Atlantic. (a) All observed drifters in grey, color tracks indicate drifters exhibiting relatively sharp inshore loops near $41^{\circ} \mathrm{S}$. The light shading marks waters shallower than $200 \mathrm{~m}$. (b) Expanded view of the region indicated by the dashed rectangle in (a) with color drifter tracks overlapped with lines of constant potential vorticity (black contours in $10^{-7} \mathrm{~m}^{-1} \mathrm{~s}^{-1}$ ). The dashed lines in (b) are the 100, 200 (shaded), 1000, 2000 and $3000 \mathrm{~m}$ isobaths from GEBCO.

enhanced slope-shelf interactions compared to other regions along the Patagonia shelf break front. Though understanding the dynamics of the slope water intrusions is beyond the scope of this paper, here we discuss the possible cause for their occurrence near $41^{\circ} \mathrm{S}$. The General Bathymetric Charts of the Oceans (GEBCO, www.gebco.net) bathymetry suggests that the steep shelf break bottom slope relaxes near $41^{\circ} \mathrm{S}$ due to the inshore deflection of the $100 \mathrm{~m}$ isobath (Fig. 1, see also Lonardi and Ewing, 1971a, b). This feature does not appear to extend to the deeper ocean, as occurs with many canyons found along the shelf break further north and south (e.g. Hernández-Molina et al, 2009). The slight depth increase $(\sim 10 \mathrm{~m})$, at the location where we observe the center of action of non seasonal SST variability (Fig. 5), suggests that the temperature anomalies in the outer shelf may be associated with this topographic feature. Based on the analysis of nine years of SST images Saraceno et al. (2004, their Fig. 9) have shown that the high SST gradient band observed along the western edge of the Malvinas Current between 39 and $44^{\circ} \mathrm{S}$ closely follows the line of constant potential vorticity $(f / H$, where $f$ is the Coriolis parameter and $H$ is the bottom depth) equal to $2 \times 10^{-7} \mathrm{~m}^{-1} \mathrm{~s}^{-1}$. More recently, Franco et al. (2008) have suggested that the surface transition between shelf and Malvinas Current waters is organized as a series of distinct thermal fronts, each following lines of constant potential vorticity, except for the western- most front located over the outer continental shelf, which is more variable. Variability of the inshore front is presumably due to reduced $f / H$ gradients and a less pronounced topographic control of the flow in the outer shelf. A range of $f / H$ contours $2 \times 10^{-7} \mathrm{~m}^{-1} \mathrm{~s}^{-1}<f / H<10^{-6} \mathrm{~m}^{-1} \mathrm{~s}^{-1}$ is plotted in Fig. 10b based on the 1 min resolution GEBCO gridded topography. Most contours are relatively smooth and follow the general northeastward orientation of the bottom slope. However, $f / H=10^{-6} \mathrm{~m}^{-1} \mathrm{~s}^{-1}$ presents a sharp inshore turn near $41^{\circ} \mathrm{S}$ (Fig. 10b), which closely matches the inshore deflection of surface drifters. Moreover, all drifters except 34012 also follow the same $f / H$ contour when they turn offshore at $\sim 40^{\circ} \mathrm{S}$. These observations therefore suggest that slope water intrusions near site A are guided by a topographic depression located in the outer shelf region, which causes the divergence of $f / H$ contours and the inshore deflection of northward flowing waters along the western edge of the Malvinas Current. A detailed inspection of available bathymetric surveys in the area reveals that the deepest areas within the associated depression are only $\sim 10 \mathrm{~m}$ deeper than the surrounding waters. This illustrates the potential influence of relatively small scale topographic features on the circulation as well as the need for detailed bathymetric charts for numerical simulations.

If the flow were steered by a topographic anomaly over the outer shelf, the intrusions ought to be a permanent feature of 

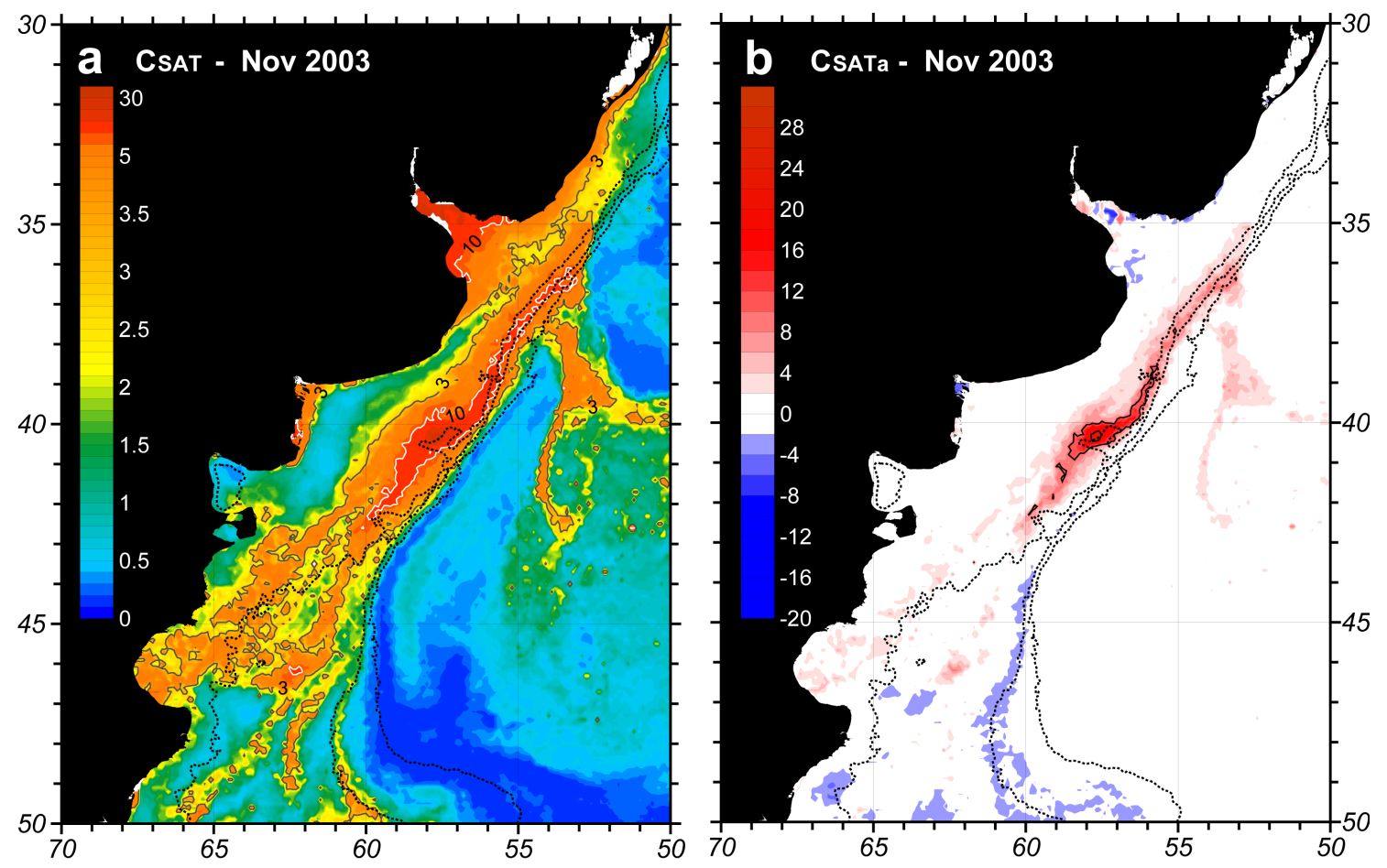

Fig. 11. (a) Mean surface chlorophyll- $a$ distribution and (b) anomaly in November 2003 based on SeaWiFS data. The $3 \mathrm{mg} \mathrm{m}{ }^{-3}$ (black) and $10 \mathrm{mg} \mathrm{m}^{-3}$ (white) contours are shown in (a) and the 10 and $20 \mathrm{mg} \mathrm{m}^{-3}$ in (b). The dotted lines in both panels are the 100,200 and $1000 \mathrm{~m}$ isobaths from GEBCO.

the regional circulation, in contrast with the findings based on the analysis of the SST variability. There are, however, various possible causes for this apparent disagreement. The characteristics of the intruding slope waters may not be clearly discernable based on SST only. This appears to be the case in winter, when cross slope SST gradients decrease (e.g. Saraceno et al., 2004). Note for example, that though the hydrographic observations of R/V Holmberg clearly indicate a relatively sharp intrusion of cold-salty slope waters (Fig. 7), the signal is barely apparent as a negative SSTa relative to the regional SST (Fig. 6). Direct current observations near $41.5^{\circ} \mathrm{S}$ show that the along shelf flow presents substantial variability in the 50-70 day band (Vivier and Provost, 1999). More recent studies also suggest a large variability in surface velocity $\left(-10\right.$ to $30 \mathrm{~cm} \mathrm{~s}^{-1}$ ), volume transport (15 to $\left.50 \times 10^{-6} \mathrm{~m}^{3} \mathrm{~s}^{-1}\right)$, and $\sim 50 \mathrm{~km}$ cross-shore fluctuations of the location of the MC core (Spadone and Provost, 2009). Thus, the intensity of the thermohaline anomalies induced by slope water intrusions may be modulated by the strength and location of the Malvinas Current. Observations and numerical simulations suggest that the region of the northern Patagonia continental slope presents low eddy energies (e.g. Goni and Wainer, 2001; Palma et al., 2008; Oliveira et al., 2009). However, high resolution satellite SST and ocean color imaging reveal a variety of small-scale eddies and filaments $(\mathrm{O}(5 \mathrm{~km})$ Capet et al., 2008), which might not be properly resolved by the relatively smoothed drifter trajec- tories and the low resolution of altimeter data. High resolution numerical models also suggest that large vertical velocities and horizontal diffusivities are associated with these submesocale features, which may play a significant role on the ecosystem (Capet et al., 2008). Though the role which such small scale features might play on the development of onshore intrusions near $41^{\circ} \mathrm{S}$ is unknown, the recurrent penetrations at that location must be a response to the bottom topography.

\section{Summary and conclusions}

We have presented evidence of intense slope water intrusions onto the northern Patagonia continental shelf near $41^{\circ} \mathrm{S}$. The surface expressions of the intrusions are a reduced surface temperature and enhanced chlorophyll- $a$ variability. The intensity and frequency of these signals cause local maxima in non-seasonal SST and Csat variability which are the largest of the shelf region and are only comparable in magnitude to those observed at the Brazil/Malvinas Confluence, a region dominated by mesoscale eddy and frontal activity. Hydrographic data reveals that the intrusions extend throughout the water column and that the temperature anomalies they generate occur with a high salinity anomaly, which confirms the offshore origin of the intruding waters. Associated with the intrusions, surface drifters describe sharp inshore 
anticyclonic turns near $41.5^{\circ} \mathrm{S}$ and then move northeastward along the outer shelf before they are ejected offshore in cross isobaths flows within a wide range of latitudes. The drifter trajectories suggest that some slope water intrusions may actually extend along the outer shelf several hundred kilometers. A plausible explanation for the persistent development of slope water intrusions near $41^{\circ} \mathrm{S}$ is the onshore deflection of constant potential vorticity contours on the western edge of the continental slope. The deflection is associated with a subtle change in bottom depth. The nature of the non-seasonal SST variability, the bimodal salinity distribution and the surface drifter trajectories suggest that inshore intrusions occurring at this location are not permanent, but the physical mechanisms leading to its time variability remain unknown.

Acknowledgements. This work was carried out with the aid of a grant from the Inter-American Institute for Global Change Research (IAI) CRN 2076 which is supported by the US National Science Foundation (GEO-0452325). Additional funding was provided by Universidad de Buenos Aires (UBACyT08-10 X176), CONICET (PIP09-112-200801), and Agencia Nacional de Promoción Científica y Tecnológica (PICT08-1874).

Edited by: J. A. Johnson

\section{References}

Acha, E. M., Mianzan, H. W., Guerrero, R. A., Favero, M., and Bava, J.: Marine fronts at the continental shelves of austral South America, physical and ecological processes, J. Mar. Syst., 44, 83-105, 2004.

Beardsley, R. C. and Flagg, C. N.: The water structure, mean currents, and shelf-water/slope-water-front on the New England continental shelf, in: Continental Shelf Dynamics, edited by: Nihoul, J. C. J., pp. 209-225, Siege de la Soc. Univ., Liege, Belgium, 1976.

Bertolotti, M. I., Brunetti, N. E., Carreto, J. I., Prenski, L. B., and Sanchez, R.: Influence of shelf-break fronts on shellfish and fish stocks off Argentina, ICES, CM. 1996/S. 41, 1996.

Bianchi, A. A., Ruiz-Pino, D., Isbert Perlender, H., Osiroff, A. P., Segura, V., Lutz, V. A., Luz Clara, M., Balestrini, C. F., and Piola, A. R.: Annual balance and seasonal variability of sea-air $\mathrm{CO} 2$ fluxes in the Patagonia Sea: Their relationship with fronts and chlorophyll distribution, J. Geophys. Res., 114, C03018, doi:10.1029/2008JC004854, 2009.

Bogazzi, E., Baldoni, A., Rivas, A., Martos, P., Reta, R., Orensanz, J. M., Lasta, M., Dell'Arciprete, P., and Werner, F.: Spatial correspondence between areas of concentration of Patagonian scallop (Zygochlamys patagonica) and frontal systems in the southwestern Atlantic, Fish. Oceanogr., 14, 359-376, 2005.

Borges, A. V., Delille, B., and Frankignoulle, M.: Budgeting sinks and sources of $\mathrm{CO}_{2}$ in the coastal ocean: Diversity of ecosystems counts, Geophys. Res. Lett., 32, L14601, doi:10.1029/2005GL023053, 2005.

Brandhorst, W. and Castello, J. P.: Evaluación de los recursos de anchoíta (Engraulis anchoita) frente a la Argentina y Uruguay.
I. Las condiciones oceanográficas, sinopsis del conocimiento actual sobre la anchoíta y el plan para su evaluación, Proy. Des. Pesq. FAO, Publication 29, 63 pp., Mar del Plata, Argentina, 1971.

Capet, X., Campos, E. J., and Paiva, A. M.: Submesoscale activity over the Argentinian shelf, Geophys. Res. Lett., 35, L15605, doi:10.1029/2008GL034736, 2008.

Carreto, J. I., Lutz, V. A., Carignan, M. O., Cucchi Colleoni, A. D., and de Marco, S. G.: Hydrography and chlorophyll a in a transect from the coast to the shelf-break in the Argentinian Sea, Cont. Shelf Res., 15, 315-336, 1995.

Chelton, D. B., Schlax, M. G., Witter, D. L., and Richman, J. G.: Geosat Altimeter Observations of the Surface Circulation of the Southern Ocean, J. Geophys. Res., 95, 17877-17903, 1990.

Franco, B. C., Muelbert, J. H., and Mata, M. M.: Mesoscale physical processes and the distribution and composition of ichthyoplankton on the southern Brazilian shelf break, Fish. Oceanogr., 15, 37-43, 2005.

Franco, B. C., Piola, A. R., Rivas, A. L., Baldoni, A., and Pisoni, J. P.: Multiple thermal fronts near the Patagonian shelf break, Geophys. Res. Lett., 35, L02607, doi:10.1029/2007GL032066, 2008.

Garcia, C. A. E., Sarma, Y. V. B., Mata, M. M., and Garcia, V. M. T.: Chlorophyll variability and eddies in the Brazil-Malvinas Confluence region, Deep-Sea Res. II, 51, 159-172, 2004.

Garcia, V. M. T., Garcia, C. A. E., Mata, M. M., Pollery, R., Piola, A. R., Signorini, S., and McClain, C. R.: Environmental factors controlling the phytoplankton blooms at the Patagonia shelfbreak in spring, Deep-Sea Res. I, 55, 1150-1166, 2008.

Glorioso, P. D., Piola, A. R., and Leben, R. R.: Mesoscale eddies in the Subantarctic Front - Southwest Atlantic, Scientia Marina, 69, Suppl. 2, 7-15, 2005.

Goni, G. and Wainer, I.: Investigation of the Brazil Current front variability from altimeter data, J. Geophys. Res., 116, 3111731128, 2001.

Gordon, A. L.: South Atlantic thermocline ventilation, Deep-Sea Res., 28, 1239-1264, 1981.

Gordon, A. L. and Greengrove, C. L.: Geostrophic circulation of the Brazil-Falkland Confluence, Deep Sea Res., Part A, 33, 573$585,1986$.

Guerrero, R. A. and Piola, A. R.: Masas de agua en la plataforma continental, in: El mar Argentino y sus recursos pesqueros, Volume 1, edited by: Boschi, E. E., Instituto Nacional de Investigación y Desarrollo Pesquero, Mar del Plata, Argentina, 107$118,1997$.

Hansen, V. H. and Poulain, P.-M.: Quality control and interpolations of WOCE/TOGA drifter data, J. Atmos. Ocean. Technol., 13, 900-909, 1996.

Hernández-Molina, F. J., Paterlini, M., Violante, R., Marshall, P., de Isasi, M., Somoza, L., and Rebesco, M.: Contourite depositional system on the Argentine Slope: An exceptional record of the influence of Antarctic water masses, Geology, 37, 507-510, doi:10.1130/G25578A.1, 2009.

Höflich, O.: Climate of the South Atlantic, in: Climates of the Oceans, edited by: Van Loon, H., World Survey of Climatology, 15, Elsevier, 1-132, 1984.

Loder, J. W., Boicourt, W. C., and Simpson, J. H.: Western ocean boundary shelves coastal segment (W), in: The Sea, edited by: Robinson, A. R. and Brink, K. H., vol. 11. Wiley, New York, 
1998.

Lonardi, A. G. and Ewing, M.: Bathymetric chart of the Argentine Basin, the Rio Grande Rise, Malvinas Plateau, Scotia Arc and Scotia Sea, Lamont Geological Observatory, Columbia University, 1971a.

Lonardi, A. G. and Ewing, M.: Sediment transport and distribution in the Argentine Basin. 4. Bathymetry of the continental margin, Argentine Basin and other related provinces. Canyons and sources of sediments, in: Physics and chemistry of the Earth, vol. 8, edited by: Ahrens, L. H., Runcorn, S. K., and Urey, H. C., Pergamon Press, Oxford, pp. 18-121, 1971 b.

Longhurst, A. R.: Ecological Geography of the Sea, Academic Press, San Diego, 398 pp, 1998.

Mariano, A. J. and Brown, O. B.: Efficient objective analysis of dynamically heterogeneous and nonstationary fields via the parameter matrix, Deep-Sea Res., 39, 1255-1271, 1992.

Martínez Avellaneda, N.: El ciclo annual y variabilidad de baja frecuencia de la temperatura superficial del mar en el Océano Atlántico sudoccidental. B.Sc thesis, FCEN, Universidad de Buenos Aires, Buenos Aires, Argentina, 132 pp, 2005.

Matano, R. P. and Palma, E. D.: On the upwelling of downwelling currents, J. Phys. Oceanogr., 38, 2482-2500, 2008.

Muller-Karger, F. E., Varela, R., Thunell, R., Luerssen, R., Hu, C., and Walsh, J. J.: The importance of continental margins in the global carbon cycle, Geophys. Res. Lett., 32, L01602, doi:10.1029/2004GL021346, 2005.

Niiler, P. P., Sybrandy, A. L., Bi, K., Poulain, P. M., and Bitterman, D.: Measurements of the water following capability of holey-sock and TRISTAR drifters, Deep-Sea Res., 42, 19511964, 1995.

Oliveira, L. R., Piola, A. R., Mata, M. M., and Soares, I. D.: Brazil Current surface circulation and energetics observed from drifting buoys, J. Geophys. Res., 114, C10006, doi:10.1029/2008JC004900, 2009.

Olson, D. B., Podestá, G. P., Evans, R. H., and Brown, O.: Temporal variations in the separation of the Brazil/Malvinas Currents, Deep-Sea Res., 35, 1971-1990, 1988.

O'Reilly, J. E., Maritorena, S., O’Brien, M. C., Siegel, D. A., Toole, D., Menzies, D., Smith, R. C., Mueller, J. L., Mitchell, B. G., Kahru, M., Chavez, F. P., Strutton, P., Cota, G. F., Hooker, S. B., McClain, C. R., Carder, K. L., Muller-Karger, F., Harding, L., Magnuson, A., Phinney, D., Moore, G. F., Aiken, J., Arrigo, K. R., Letelier, R., and Culver, M.: SeaWiFS Postlaunch Calibration and Validation Analyses, Part 3. NASA Tech. Memo. 2000-206892, vol. 11, edited by: Hooker, S. B. and Firestone, E. R., NASA Goddard Space Flight Center, 49 pp., 2000.

Palma, E. D., Matano, R. P., and Piola, A. R.: A numerical study of the Southwestern Atlantic Shelf circulation: Stratified ocean response to local and offshore forcing, J. Geophys. Res., 113, C11010, doi:10.1029/2007JC004720, 2008.

Penduff, T., Barnier, B., Béranger, K., and Verron, J.: Comparison of near-surface mean and eddy flows from two numerical models of the South Atlantic Ocean, J. Geophys. Res., 160, 1685716867, 2001.

Peterson, R. G.: The boundary currents in the western Argentine Basin, Deep-Sea Res., 39, 623-644, 1992.

Piola, A. R. and Gordon, A. L.: Intermediate waters in the southwest South Atlantic, Deep-Sea Res. A, 36, 1-16, 1989.

Piola, A. R., Campos E. J. D., Möller O. O., Charo, M., and
Martínez, C.: Subtropical shelf front off eastern South America, J. Geophys. Res., 105, 6566-6578, 2000.

Piola, A. R., Matano, R. P., Palma, E. D., Möller, O. O., and Campos, E. J. D.: The influence of the Plata River discharge on the western South Atlantic shelf, Geophys. Res. Lett., 32, L01603, doi:10.1029/2004GL021638, 2005.

Podestá, G. P.: Utilización de datos satelitarios en investigaciones oceanográfica y pesqueras en el Océano Atlántico Sudoccidental, in: El mar argentino y sus Recursos Pesqueros, Volume 1, edited by: Boschi, E. E., Instituto Nacional de Investigación y Desarrollo Pesquero, Mar del Plata, Argentina, 195-222, 1997.

Podestá, G. P.: Migratory pattern of Argentine hake (Merluccius hubbsi) and oceanic processes in the southwestern Atlantic Ocean, Fishery Bulletin, 88, 167-177, 1989.

Podestá, G. P., Brown, O. B., and Evans, R. H.: The annual cycle of satellite-derived sea surface temperature in the southwestern Atlantic Ocean, J. Climate, 4, 457-467, 1991.

Presiendorfer, R. W.: Principal component analyses in meteorology and oceanography, Elsevier, 426 pp., 1998.

Rivas A. L.: Spatial variation of the annual cycle of temperature in the Patagonian shelf between 40 and $50^{\circ}$ of south latitude, Cont. Shelf Res., 14, 1539-1554, 1994.

Rivas, A. L. and Piola, A. R.: Vertical stratification on the shelf off northern Patagonia, Cont. Shelf Res., 22, 1549-1558, 2002.

Rivas, A. L., Dogliotti, A. I., and Gagliardini, D. A.: Seasonal variability in satellite-measured surface chlorophyll in the Patagonian Shelf, Cont. Shelf Res., 26, 703-720, 2006.

Rivas, A. L. and Pisoni, J. P.: Identification, characteristics and seasonal evolution of surface thermal fronts in the Argentinean Continental Shelf, J. Mar. Syst., 79, 134-143, doi:10.1016/j.jmarsys.2009.07.008, 2010.

Rodhouse, P. G., Elvidge, C. D., and Trathan, P. N.: Remote sensing of the global light-fishing fleet: an analysis of interactions with oceanography, other fisheries and predators, Adv. Mar. Biol., 39, 261-303, 2001.

Romero, S. I., Piola, A. R., Charo, M., and Garcia, C. A. E.: Chlorophyll-a variability off Patagonia based on SeaWiFS data, J. Geophys. Res., 111, C05021, doi:10.1029/2005JC003244, 2006.

Sanchez, R. and Ciechomski, J. D.: Spawning and nursery grounds of pelagic fish species in the sea-shelf off Argentina and adjacent areas, Sci. Mar., 59, 455-478, 1995.

Saraceno, M., Provost, C., Piola, A. R., Bava, J., and Gagliardini, A.: Brazil Malvinas Frontal System as seen from 9 years of advanced very high resolution radiometer data, J. Geophys. Res., 109, C05027, doi:10.1029/2003JC002127, 2004.

Saraceno, M., Provost, C., and Piola, A. R.: On the relationship of satellite retrieved surface temperature fronts and chlorophyll$\mathrm{a}$ in the Western South Atlantic, J. Geophys. Res., 110, C11016, doi:10.1029/2004JC002736, 2005.

Signorini, S. R., Garcia, V. M. T., Piola, A. R., Garcia, C. A. E., Mata, M. M., and McClain, C. R.: Seasonal and interannual variability of coccolithophore blooms in the vicinity of the Patagonian shelf break ( $\left.38^{\circ} \mathrm{S}-52^{\circ} \mathrm{S}\right)$, Geophys. Res. Lett., 33, L16610, doi:10.1029/2006GL026592, 2006.

Signorini, S. R., Garcia, V. M. T., Piola, A. R., Evangelista, H., McClain, C. R., Garcia, C. A. E., and Mata, M. M.: Further studies on the physical and biogeochemical causes for large interannual changes in the Patagonian shelf spring-summer phytoplankton 
bloom biomass. NASA Technical Memorandum, NASA/TM2009-214176, Greenbelt, MD, 43 pp, 2009.

Soares, I. and Möller Jr., O.: Low-frequency currents and water mass spatial distribution on the southern Brazilian shelf, Contin. Shelf Res., 21, 1785-1814, 2001.

Souza, R. B. and Robinson, I. S.: Lagrangian and satellite observations of the Brazilian Coastal Current, Cont. Shelf Res., 24, 241-262, 2004.

Spadone, A. and Provost, C.: Variations in the Malvinas Current volume transport since October 1992, J. Geophys. Res., 114, C02002, doi:10.1029/2008JC004882, 2009.

Vivier, F. and Provost, C.: Direct velocity measurements in the Malvinas Current, J. Geophys. Res., 104, 21083-21103, 1999.

Volkov, D. L. and Fu, L.-L.: The role of vorticity fluxes in the dynamics of the Zapiola Anticyclone, J. Geophys. Res., 113, C11015, doi:10.1029/2008JC004841, 2008.
Vörösmarty, C. J., Fekete, B. M., and Tucker, B. A.: Global river discharge data base (RivDIS v1.0), Volume 5, International Hydrological Programme, Technical Documents in Hydrology, United Nations Educational, Scientific and Cultural Program, 123 pp, 1996.

Yu, L. and Weller, R. A.: Objectively Analyzed air-sea heat fluxes for the global ice-free oceans (1981-2005), B. Am. Meteorol. Soc., 88, 527-539, 2007.

Yu, L., Jin, X., and Weller, R. A.: Multidecade Global Flux Datasets from the Objectively Analyzed Air-sea Fluxes (OAFlux) Project: Latent and sensible heat fluxes, ocean evaporation, and related surface meteorological variables. Woods Hole Oceanographic Institution, OAFlux Project Technical Report, OA-2008-01, 64 pp., Woods Hole, Massachusetts, 2008. 